\title{
Illegal, Unreported, and Unregulated Fishing as Transnational Organized Crimes
}

\author{
Elisabeth Septin Puspoayu ${ }^{1 *}$ and Peni Jati Setyowati ${ }^{2}$ \\ ${ }^{1}$ Department of Law, Faculty of Law and Social Sciences, Universitas Negeri Surabaya, Indonesia \\ ${ }^{2}$ Department of Law, Faculty of Law and Social Sciences, Univesitas Negeri Surabaya, Indonesia
}

\begin{abstract}
IUU Fishing (Illegal, Unreported, and Unregulated Fishing) is a fishing activity conducted in territorial waters or EEZ of a country that is unlawfully or unlicensed, and it is not reported or incorrectly reported either on its operations or the data of the vessels and its catch to the authorized fisheries institution. IUU fishing criminals are often a group of foreign organized crime that may cause the implementation of legal proceedings against IUU fishing perpetrators will be more difficult due to the limitations of coastal state jurisdiction. IUU fishing has become a global threat because this crime has occurred in many countries and resulted in enormous losses to the coastal state. Therefore, IUU fishing needs to be recognized as a transnational organized crime. The classification of IUU fishing as an organized transnational crime will facilitate the process of eradicating the practice of IUU fishing because every country should cooperate in the settlement and prevention of IUU fishing crime. Thus, IUU fishing is not only the responsibility of the coastal state alone, but also the global responsibility.
\end{abstract}

\section{Introduction and Literature Review}

Illegal, Unreported and Unregulated Fishing (IUUF) is a fishing activity that is prohibited according to international sea law; the prohibition is mainly because the three fishing activities that may harm coastal countries and other interested countries in the sea area. According to the International Plan of Action to prevent, deter and eliminate Illegal, Unreported and Unregulated Fishing (IPOA-IUU), IUUF activities consist of three prohibited activities, namely: a) illegal fishing, which is fishing activities carried out by foreign people or ships in state territorial or EEZ territorial waters of a country that do not have permission, or else the activities are contrary to the state rules of the country [1]; b) unreported fishing, which is a fishing activity in territorial waters or Exclusive Economic Zone (EEZ) of a country that is not reported or incorrectly reported in terms of the data of the vessels, vessel operations, the number of fish catches obtained by the vessels to the authorized fishery management or institution. This activity is later known as an illegal transshipment by foreign vessels in the high seas; c) unregulated fishing, which is fishing activities in regional waters or EEZ of a country that is not or has not

\footnotetext{
* Corresponding author : aiuelisabeth@gmail.com
} 
been regulated or stipulated in the existing regulations, or carried out in an area or fish stock that has not been applied for conservation provisions and management [2]. IUUF activities are fisheries activities that may affect and harm fish supplies as well as the safety of coastal countries.

The development of IUUF activities in several countries has been increasingly detrimental, for example in Indonesia, where there is no clear mechanism for recording and reporting fisheries products obtained by fishermen, both local and foreign fishermen; the condition has been resulting in losses to the Indonesian government in the fisheries sector, including the emerging trades of illegal drugs through fishing boats which are a new mode of crime through the sea region [3]. Indonesia, which is a coastal and archipelagic country, becomes a potential place that is often targeted by IUUF actors to commit crimes in the field of fisheries. Some IUUF crimes in Indonesian waters include: a) illegal fishing activities have been done in the Arafuru and Raja Ampat Seas, b) The Ministry of Maritime Affairs has made arrests of foreign vessels containing 1,200 tons of fish with 32 different state flags [3], c) smuggling of illegal drugs whose mode is fishing vessels that sail in the waters of the Indonesian EEZ waters, including the falsification of the size and identity of fishing vessels (Indonesian emergency of IUUF) [4].

Of the several cases concerning with the IUUF that occurred in some coastal regions, it should be categorized as a crime that violated the national laws of coastal countries and also international sea law. Every vessel that committed the IUUF crime is likely to have involved more than one country in terms of the crews. If the illegal activity is carried out by citizens from one coastal country where it takes place, this case will be resolved using the national law of the coastal country; but if it involves foreign citizens, international law will be used. Any cross-border crimes by nature are detrimental to the coastal states in terms of the financial, economic, social, environmental and ecological aspects. Such losses due to these activities are experienced by coastal countries, which are mainly classified as developing countries, such as Indonesia.

As it stands, it is not only about stealing the fishery products that are in the sea territory of the coastal states, but it also has grown beyond into one type of transnational crime. Based on the background above the author is interested in discussing more about the issues related with illegal, unreported and unregulated fishing activities as transnational organized crimes.

\subsection{Transnational Organized Crime (TOC)}

Transnational organized crimes (TOC) began to emerge around the end of the $20^{\text {th }}$ Century, as the development of technology and ease in terms of law and sales of goods and services, which triggered the emergence of transnational crimes. Organized transnational crime can be defined as an act of cross-border crime, in this case including the perpetrator, the place of effect and the purpose of the crime [5].

The nature of TOC has lead into some problems experienced by some countries, including in terms of the determination of the perpetrators, locus delicti, and which laws or regulations should be referred to process the perpetrators. Article 3 Section 2 of United Nations Conventions against Transnational Organized Crimes states some requirements that can be the reference in categorizing which crimes that belong to transnational organized crimes, namely, (a) it is committed in more than one state; (b) it is committed in one state but a substantial part of its preparation, planning, direction or control takes place in another state; (c) it is committed in one state but involves an organized criminal group that engages in criminal activities in more than one state; or (d) it is committed in one state but has substantial effects in another state [6]. 
This convention aims to ensure that the participating countries in this convention regulate criminalization in their national law for all actions that are generally related to organized crime groups [7], and in addition for cooperation among participating countries in this convention in handling and combating transnational organized crimes [6]. Other kinds of organized crimes include: corruption, money laundering, and the participation of organized crime groups, and obstacle in obtaining justice, human trafficking, immigrants, and illicit trade in firearms, cybercrime, and narcotics.

\subsection{Illegal, Unreported and Unregulated Fishing}

According to the International Plan of Action to prevent, deter and eliminate Illegal, Unreported and Unregulated Fishing (IPOA-IUU), IUUF activities consist of three prohibited activities, namely: illegal fishing, which is fishing activities carried out by foreign people or ships in state territorial or EEZ territorial waters of a country that do not have permission, or else the activities are contrary to the state rules of the country [1]. Such activities included in Illegal Fishing cover fishing activities carried out by people or fishers in a waters that are under jurisdiction of a country without permit and/or in contravention of applicable national and international regulations, falsification of vessel permits, the use of prohibited equipment while fishing, and fishing the species of which does not comply with permits granted by the government of coastal state.

Unreported fishing is a fishing activity in territorial waters or EEZ of a country that is not reported or incorrectly reported in terms of the data of the vessels, vessel operations, the number of fish catches obtained by the vessels to the authorized fishery management or institution. Activities that are include unreported fishing namely incorrect reporting of fishing catches by ships carrying out activities in the area of the coastal state to the authorized institutions. This activity is later known as an illegal transshipment by foreign vessels in the high seas.

Unregulated fishing is fishing activities in regional waters or EEZ of a country that is not or has not been regulated or stipulated in the existing regulations, or carried out in an area or fish stock that has not been applied for conservation provisions and management [2], including the fishing activities by vessels in the high seas without raising the country's flag [8].

\section{Objectives of the Study}

This article is intended to discuss the criteria for illegal, unreported and unregulated fishing (IUUF) to be categorized as transnational organized crime in international law.

\section{Methodology}

The research method utilized normative juridical legal research [9]. The method of collecting legal material used was through literature study. Legal materials were derived from primary and secondary law sources in the form of primary legal materials referred to the provisions of international law, namely in the form of international conventions related to the issues under study; secondary legal materials were obtained from literature, lecture materials, other literature books or works of international jurists who may provide explanations related to the provisions of international law, particularly those related to illegal, unreported and unregulated fishing and transnational organized crimes.

In this normative legal research, the legal material that has been obtained was analyzed qualitatively by giving interpretation of the legal material obtained from various sources, 
and the analyses of the legal materials were assisted by using prescriptive method to answer the existing problems [10].

\section{Discussions}

ransnational organized crime is a crime that is carried out in an organized manner and cross-border state by nature. Not all cross-border crimes then constitute the TOC; there are several elements that should be fulfilled in order to be categorized as international organized crime. Illegal, unreported, and unregulated fishing (IUUF), as its development nowadays, harms both coastal countries and the international community. Such losses experienced by the coastal states include the financial, social, and environmental and ecosystem environments of the marine environment. As stipulated in Article 3 Section 2 of the United Nations Convention against Transnational Organized Crime includes some elements that can be the reference to categorize a crime can be said to be international organized crime. These elements include:

Committed by perpetrators from more than one country. The actors and the place where IUUF activities occur are usually located in waters area of a coastal country, both in the Exclusive Economic Zone (EEZ) and the high seas that are directly adjacent to certain coastal countries. The perpetrators, the ship crews in such crime, usually come from foreign countries (nationalities) and even falsify the flag (according to where the country they may take actions) of the vessels that is used for fishing activities in the sea area. In the IIUF case of FV Viking, the vessel has several flags of different countries when carrying out illegal fishing in coastal countries. This ship has become the target of Interpol at the request of the Norwegian government who felt it was harmed by the actions taken by the crews of the FV Viking vessels which has caught toothfish fishes in the Antarctic region [11]. The crews of the FV Viking, according to the checking process, consist of citizens from Peru, Myanmar and Indonesia from. For this case, the activities carried out by FV Viking are one form of international organized crime. The existence of elements of foreign citizens and the cooperation carried out by Indonesian citizens to carry out fish catch in the high seas area. The cases of IUUF crimes are increasingly difficult to solve if the perpetrators manage to escape and enter the territorial waters of other countries, and worse if there are attempts to protect the IUUF criminals by some parties. The completion of the IUUF case requires commitment and cooperation from the international community.

Based on reports from the Food and Agriculture Organization (FAO) due to the increasing number of IUUF crimes have resulted in serious problems in the fisheries sector, particularly in developing countries in from which main occupation of the community depends on this sector. The following are some data related to the losses that must be covered by the (coastal) countries due to the rampant IUUF activities: a) illegal capture of sockeye salmon from Russia which resulted in losses suffered by Russia for US\$ 40-74 million, b) due to IUUF activities in 2006 only, Sub-Saharan region suffered a loss of US\$ 1 billion per year, c) in 2009, illegal fishing in the Pacific Ocean reached 786,000 tons to $1,730,000$ tons with a total loss of US\$ 105 to 707 billion.

There are serious impacts to the coastal countries due to IUUF activities; IUUF activities have detrimental impacts on the coastal countries, namely in the financial sector in the form of decreased GNP because of the decreasing number of fish catches. In Kenya, for example, fishery yield has decreased by $50 \%$ from the normal country's ability of $75 \%$ exploration year [12], the declining in state tax revenues from the fisheries sector [13], and the IUUF has also resulted in losses to the coastal state decreased supply of fishery products for domestic consumption starting from the 
processing, packing, and marketing of the fishery products for domestic consumption [13]. The IUUF may also put the environment and ecology of marine countries in jeopardy due to uncommon methods and procedures utilized by the IUUF perpetrators such as the use fishing gear that is prohibited and dangerous for the marine environment ecosystem. One of the cases is the FV Viking which utilized the bottom gillnet which has a range of $399 \mathrm{~km}$, while the limit of the gillnet net is only $2.5 \mathrm{~km}$ ). The use of bombs to facilitate fishing is also often used by the fishermen in committing IUUF. The IUUF practices are very detrimental to the coastal states which have the obligation to maintain and take care for the marine environment in accordance with UNCLOS 1982 [13].

In the United Nations Convention Against Transnational Organized Crime, there are several responsibilities of the state in overcoming transnational organized crime, including: a) categorizing all crimes committed by organized groups as a form of crime, b) increasing cooperation among member states of the convention in the framework of implementing this convention, and c) developing a series of regulations regarding actions to combat organized transnational crimes. This Covenant is considered effective to overcome and curb organized transnational crimes, especially in relation with IUU Fishing activities that can later be classified in one form the transnational crime. Combating transnational organized crime in this Convention is the joint responsibility of the international community and coastal states, which work together to prevent the emergence of IUU Fishing crimes.

\section{Conclusion}

Corroborated the discussion, it can be concluded that illegal, unreported and unregulated fishing activity can be categorized as a transnational organized crime because a) it is carried out by people or groups from various countries, b) it may cause a massive impact not only for coastal countries, but also for the international community. This further strengthens that illegal, unreported and unregulated fishing can be categorized as transnational organized crime, in accordance with Article 3 Section 2 of the United Nations Convention against Transnational Organized Crime.

\section{References}

1. S. Newman, Eur. Union Action to Fight Enviromental Crime, 4, 1-17 (2015)

2. FAO, International Plan of Action to Prevent, Deter and Eliminate, Illegal, Unreported and Unregulated Fishing, 4, 185-201 (2001).

3. A. Maulana, Indonesia Darurat IUU Fishing, (Bandung, 2017).

4. D. A. Varkey, C. H. Ainsworth, T. J. Pitcher, Y. Goram, and R. Sumaila, Mar. Policy, 34, 228-236 (2010)

5. H. Harkrisworo, “39203-EN-transnational-organized-crime-dalam-perspektif-hukumpidana-dan-kriminologi.pdf." (2004)

6. U. Nations, Trends Organ. Crime, 5, 11-21 (2000)

7. R. Atasasmita, Dampak ratifikasi konvensi transnational organized crime (toc). (BPHN, Jakarta, 2014)

8. R. Baird, Melb. J. Int. Law, 5, 299-334 (2004)

9. J. Ibrahim, Teori dan Penelitian Hukum Normatif, I. (Bayumedia Publishing, Malang, 2006).

10. E. S. Puspoayu, Pemberian Humanitarian Assistance Dalam Situasi Konflik Bersenjata Menurut Hukum Internasional ( Studi Kasus Syrian Arab Republic ), 
(Gadjah Mada, Yogyakarta, 2013)

11. I. Mcphee, 6 (2008)

12. WWF, An Analysis of the Impact of IUU Imports on U.S. Fishermen, (2016)

13. M. Marine, R. Assessment, Review of Impacts of Illegal, Unreported and Unregulated Fishing on Developing Countries, Final Report July 2005, July, 2005. 